J. Product. \& Dev., 22(3): 715 - 728 (2017)

\title{
EVALUATE PLANT GROWTH, GREEN POD YIELD AND ITS QUALITY OF THE TWO PEA CULTIVARS ENTSAR 1 AND MASTER B WITH DIFFERENT PLANT DENSITIES
}

\author{
Wafaa, A. Fekry ${ }^{1}$ and Rowaa, S. El-Shatoury ${ }^{2}$ \\ ${ }^{1}$ Plant Production Department, Faculty of Technology and Development, \\ Zagazig University, Egypt. \\ ${ }^{2}$ Horticulture Department, Faculty of Agriculture, Suez Canal University, Egypt .
}

\section{ABSTRACT}

This work was carried out during the two winter seasons of 2014/2015 and 2015/2016 at the Experimental Farm(GhazalaZagazig), Faculty of Technology and Development, Zagazig University, Sharkia Governorate, Egypt to evaluate the new pea cultivars Entsar 1 under the three rates of plant densities, i.e. 40, 50 and 60 plant $m^{-2}$ compared with the traditional variety Master $B$ on plant growth, total green pod yield and its quality.

The obtained results showed that: The two pea cultivars had significant differences in most studied characters. Entsar $1 \mathrm{cv}$. had the best results of most vegetative growth characters, i.e. plant length, number of leaves, fresh and dry weight plant ${ }^{-1}$, as well as the total chlorophyll content of pea leaves. Moreover, it had the maximum total green pod yield per feddan with high pod quality (pod length, diameter, number of seeds as well as fresh weight of pod and its green seed) and 1000-seed fresh and dry weight. Meanwhile, the cv. Master $B$ recorded the highest value of plant length only. From that, the cultivar Entsar 1 with plant density 40 plant $m^{-2}$ had the best plant growth and higher characters quality of the green pods, whereas the density 60 plant $\mathrm{m}^{-2}$ for the highest total green pod yield may be suggested for the winter green pea.

Conclusively, it can be recommended to replace the old pea variety Master B with the new one Entsar 1 to sowing under clay soil condition at the plant density 40 plant $\mathrm{m}^{-2}$, where it gave 48.73 and $49.69 \%$ yield advantage, respectively during the two growing seasons of this study.

Keywords: Evaluate plant growth, green pod yield \&s quality, pea cultivars, entsar 1 and master $b$, different plant densities 


\section{INTRODUCTION}

Pulses considered a high protein foods that are demand for human and animal nutrition in the world. Pea (Pisum sativum L.) is one of the most important popular pulse crop used by livestock feed and human nutrition. Green pea, field pea or dry pea and podded sugar peas (eaten as whole pods), known as a winter-season legume cultivated around the world. FAO use the term green pea for peas harvested when the seed is green and tender succulent to be eaten as fresh or processed (canned or frozen). Pea and other legumes were very beneficial effect on soil which improves the fertility and properties especially soil organic nitrogen (Carranca et al., 1999), the biological activities and organic matter of it (Piotrowska and Wilczewski, 2012). Seeds of pea are very rich of protein content (23 to $31 \%$ of seed dry matter), carbohydrates, various minerals and fibres (Swiatecka et al., 2010 and Dahl et al., 2012).

Cultivated pea had a much genetic variation and this make a big variance of varieties and its traits (Karkanis et al., 2016). The choice of type and variety of crop affected on its growth and yield.

Increasing productivity of pea with good quality is an important aim for the growers. This aim could be achieved through choosing the suitable agricultural practices among them, cultivars and plant density (the methods to condensate the plants in the unit area).

Many investigators studied the differences between the varieties in most characters and how that affect on their productivity. Nosser and Bhnan (2010) observed the variance between pea cultivars in plant growth parameters, i.e. plant length, number of branches and leaves plant ${ }^{-1}$, total green yield, weight of 100 seeds as well as pod quality (pod weight and number of seed pod ${ }^{-1}$. Yucel (2013) sown two cultivars of pea and recorded their significant differences effect on plant length and 1000-seed weight. Moreover, Bitew et al. (2014) indicated that the two pea varieties used varied from each others in plant length, number of seed pod $^{-1}$ and 1000 seed weight. In this respect, Byan et al. (2015) cultivated the two pea varieties Master B and Entsar 1, the results demonstrated the high differences between them in all studied features (plant length, number of leaves and fresh weight plant ${ }^{-1}$, total chlorophyll, as well as total green pod yield and pod characters (length, diameter, weight and number of seeds pod ${ }^{-1}$ ).

Plant density and planting method are among the important factors realized with growth and high yield of pea plants. In general, maximum yield related with increasing the number of plants per the unit area to the optimum rate. Meanwhile, the high plant population in the unit area had 
adversely relationship with plants growth, yield and its quality due to the competition between the greatest plants and their needs to availability of moisture, light and nutrients (Sibhatu et al., 2016). On the other side, if plant density decrease than the recommended rate the yield will be declined.

In this concern, Nosser and Bhnan (2010) found that sowing pea seeds on one side of ridge recorded the highest values of vegetative growth parameters, increased weight and number of seed pod ${ }^{-1}$, as well as 100-seeds weight compared with grown in the two and three sides of ridge. Meanwhile, the total green yield was increased by sown on three sides of ridge. Moreover, Yucel (2013) reported that plant density of 30 or 40 plant $\mathrm{m}^{-2}$ may be the best for plant height and total pod numbers. In the same line, Byan et al. (2015) recommended a plant density between 30 and 40 plant $\mathrm{m}^{-}$ 2 which increased plant length, number of leaves and fresh weight plant ${ }^{-1}$, as well as total chlorophyll, green pod characters (length, diameter, weight and number of seeds $\operatorname{pod}^{-1}$ ). While the increase of total green pods of pea obtained by 80 plant $\mathrm{m}^{-2}$. Both Bitew et al. (2014) and Sibhatu et al. (2016) found that plant spacing as row and inter-row spacing had impact effect on pea growth, yield and its components.

Generally, the cultivar Master B considered one of the most traditional variety sown in Egypt since many years ago. Recently, this cultivar suffer from deterioration of their growth parameters and decrease in its productivity and quality. These disadvantages may be related to that growers produced seeds with themselves and to high differences of environmental factors especially the temperature as a regulate of global warming. Therefore, Horticulture Research Institute, Agricultural Research Center, Egypt came to produced and registered two new cultivars of green pea termed Entsar 1 as a short stem length and Entsar 2 as a medium long stem length.

Hence, the aim of this study was to evaluate and investigate the effect of plant density on growth parameters and productivity of the new variety Entsar 1 compared with the widely pea grown cultivar Master B.

\section{MATERIALS AND METHODS}

Two field experiments were carried out during the two winter seasons of 2014/2015 and 2015/2016 at the Experimental Farm in Ghazala regionZagazig, Faculty of Technology and Development, Zagazig University in, Sharkia Governorate, Egypt to compare between the two cultivars Master B and Entsar 1 under three plant densities, i.e. 40, 50 and 60 plant $\mathrm{m}^{-2}$ on plant growth characters and pod green yield, as well as pod quality. 
The texture of soil was clay with a $\mathrm{pH}$ value of 7.9-8.1,organic matter was 1.6-1.9\% and the available N25-30, P 22-20 and K 300-320 ppm in the $1^{\text {st }}$ and $2^{\text {nd }}$ seasons, respectively.

The experiment was layout in a split plot design with three replications, where the two cultivars (Master B and Entsar 1) were randomly arranged in the main plots, meanwhile the three plant densities (40,50and 60 plant $\mathrm{m}^{-2}$ ) were randomly distributed in the sub-plots.

The seeds of the two pea cultivars were inoculated with $\mathrm{N}$-fixed bacteria Rhizobium leguminosarum. Inoculated seeds were sown on $15^{\text {th }}$ and $20^{\text {th }}$ November in both growing seasons. Plant spacing and densities were shown in Table 1.

Table 1: Plant density and average plant spacing, plot size and number of rows per ridge as well as plants per row.

\begin{tabular}{|c|c|c|c|c|c|c|c|c|}
\hline $\begin{array}{c}\text { Plant } \\
\text { density }\end{array}$ & \multicolumn{2}{|c|}{$\begin{array}{c}\text { Average plant } \\
\text { spacing (cm) }\end{array}$} & \multicolumn{4}{c|}{$\begin{array}{c}\text { Plot size } \\
\left(\mathbf{m}^{-2}\right)\end{array}$} & $\begin{array}{c}\text { No. of } \\
\text { rows } \\
\text { ridge }^{-1}\end{array}$ & $\begin{array}{c}\text { Average } \\
\text { plants }_{\text {row }^{-1}}\end{array}$ \\
\hline $\mathbf{m}^{-2}$ & $\begin{array}{c}\text { Between } \\
\text { rows }\end{array}$ & $\begin{array}{l}\text { Inter- } \\
\text { raw }\end{array}$ & $\begin{array}{c}\text { No. of } \\
\text { ridges }\end{array}$ & $\begin{array}{c}\text { Ridge } \\
\text { length } \\
(\mathbf{m})\end{array}$ & $\begin{array}{c}\text { Ridge } \\
\text { width } \\
(\mathbf{m})\end{array}$ & Net & & \\
\hline 40 & 30.00 & 8.00 & 3.00 & 3.00 & 0.60 & 5.40 & 2.00 & 38.00 \\
\hline 50 & 25.00 & 8.00 & 3.00 & 3.00 & 0.80 & 7.20 & 3.00 & 38.00 \\
\hline 60 & 20.00 & 8.00 & 3.00 & 3.00 & 0.90 & 8.10 & 4.00 & 38.00 \\
\hline
\end{tabular}

The source of pea cvs. Master B and Entsar 1 was Hort. Res. Inst., Agric. Res. Center, Egypt. The source of $\mathrm{N}$-fixing bacteria was the General Organization for Agriculture Equalization for Agriculture Equalization found (GOAEF), Ministry of Agric., Egypt.

Plants were fertilized with $200 \mathrm{Kg} /$ fed. ammonium sulphate $(20.5 \% \mathrm{~N})$, $200 \mathrm{~kg} / \mathrm{fed}$. calcium superphosphate $\left(16-18 \% \quad \mathrm{P}_{2} \mathrm{O}_{5}\right)$ and $100 \mathrm{~kg} / \mathrm{fed}$. potassium sulphate $\left(48 \% \quad \mathrm{~K}_{2} \mathrm{O}\right)$ as sources of $\mathrm{N}, \mathrm{P}$ and $\mathrm{K}$ fertilizers, respectively. $150 \mathrm{~kg} / \mathrm{fed}$. from the phosphorus fertilizer was added during the preparation of soil. The amount of both nitrogen and potassium fertilizers were divided into equal portions, the first added to the soil beside $50 \mathrm{~kg} / \mathrm{fed}$ of the phosphorus fertilizers after complete emergence and the second during flowering stage. The other cultural practices of growing pea plants were followed as recommended.

After 50 days from sowing, data were recorded for both cultivars, i.e. Master B and Entsar 1 by taken a random sample of six plants from each plot to measure:

Plant growth parameters, i.e. plant length $(\mathrm{cm})$, number of branches and leaves plant ${ }^{-1}$, as well as fresh and dry weight plant $^{-1}(\mathrm{~g})$. 
Total chlorophyll was assessed in fresh leaves by using Spad 502 chlorophyll Meter designed by Minolta Camera Co. Ltd., Japan.

Total green pod yield: Green pods of each plot were harvested at the suitable maturity stage ( 80 days after sowing), counted and weight in each harvest of both cultivars to record: yield of green pods $\mathrm{Kg} \mathrm{plot}^{-1}$ and ton fed. ${ }^{-1}$, as well as 1000 green and dry seed weight $(\mathrm{g})$.

Green pod quality: At the second harvest, 20 mature pods were randomly chosen from each plot and the physical characters of pod were recorded: pod length $(\mathrm{cm})$, pod diameter $(\mathrm{cm})$, number of seeds $\operatorname{pod}^{-1}$ and average fresh weight $\operatorname{pod}^{-1}(\mathrm{~g})$, as well as fresh weight of green seed $\operatorname{pod}^{-1}(\mathrm{~g})$.

Statistical analysis: Data for the two growing seasons were statistically analysis of variance using SAS 9.2 software (SAS, 2008). The differences between treatments were tested for significance using LSD at 5\% probability.

\section{RESULTS and DISCUSSION}

\section{Plant Growth Parameters}

\section{a) Effect of cultivars:}

Results presented in Table 2 reflect the significant differences between Master B and Entsar 1 cultivars in all studied plant growth characters, except number of branches plant ${ }^{-1}$. Entsar $1 \mathrm{cv}$. show the excel in most vegetative parameters, i.e. number of leaves plant ${ }^{-1}$, fresh and dry weight of whole plant during both seasons of study. On the other hand, Master B $\mathrm{cv}$. recorded the highest value of plant length only in this respect.

These results are in accordance with those of Nosser and Bhnan (2010); Munakamwe et al. (2012); Urbatzka et al. (2012); Yucel (2013); Byan et al. (2015) and Karkanis et al. (2016). They concluded that cultivated pea had a much genetic variation which due to the differ in plant growth characters.

\section{b) Effect of plant density:}

It is evident from data in Table 2 that there were gradual increase in plant length by increasing the density from 40, 50 up to 60 plant $\mathrm{m}^{-2}$. The highest value of plant length was obtained by the density 60 plant $\mathrm{m}^{-2}$. Moreover, the optimum number of leaves, fresh and dry weight of plant were achieved by the low plant density ( 40 plant $\mathrm{m}^{-2}$ ). On the other hand, all plant densities treatments used had no significant differences of number of branches plant ${ }^{-1}$ in the two growing seasons. 
Table 2: Influence of cultivars and plant density $\left(\mathrm{m}^{-2}\right)$ on plant growth characters and leaves total chlorophyll of pea plants during 2014/2015 and 2015/2016 seasons.

\begin{tabular}{|c|c|c|c|c|c|c|c|}
\hline \multirow{2}{*}{\multicolumn{2}{|c|}{ Treatments }} & $\begin{array}{c}\text { Plant } \\
\text { length } \\
(\mathrm{cm})\end{array}$ & $\begin{array}{c}\text { No. of } \\
\text { branches } \\
\text { plant }^{-1}\end{array}$ & $\begin{array}{l}\text { No. of } \\
\text { leaves } \\
\text { plant }^{-1}\end{array}$ & $\begin{array}{c}\text { Fresh } \\
\text { weight } \\
\text { plant }^{-1} \\
\text { (g) }\end{array}$ & $\begin{array}{c}\text { Dry } \\
\text { weight } \\
\text { plant }^{-1} \\
\text { (g) }\end{array}$ & $\begin{array}{c}\text { Total } \\
\text { chlorophyl } \\
\text { l } \\
\text { (Spad) }\end{array}$ \\
\hline & & \multicolumn{6}{|c|}{$2014-2015$ season } \\
\hline \multicolumn{2}{|c|}{ Master B } & 44.63 & 2.11 & 16.78 & 20.27 & 4.16 & 47.43 \\
\hline \multicolumn{2}{|l|}{ Entsar 1} & 40.16 & 2.33 & 19.36 & 31.46 & 6.65 & 51.30 \\
\hline \multicolumn{2}{|l|}{ LSD (0.05) } & 0.75 & N.S & 1.06 & 1.08 & 0.29 & 1.52 \\
\hline \multicolumn{8}{|c|}{ Plant density $\left(m^{-2}\right)[D]$} \\
\hline \multicolumn{2}{|c|}{40} & 39.66 & 2.17 & 19.95 & 29.18 & 5.92 & 52.52 \\
\hline \multicolumn{2}{|c|}{50} & 42.33 & 2.33 & 17.74 & 25.35 & 5.51 & 49.78 \\
\hline \multicolumn{2}{|c|}{60} & 44.98 & 2.16 & 16.53 & 23.05 & 4.79 & 45.80 \\
\hline \multicolumn{2}{|c|}{ LSD $(0.05)$} & 1.42 & N.S & 0.81 & 2.15 & 0.42 & 1.59 \\
\hline \multicolumn{8}{|c|}{ Interaction [Cx $\mathrm{D}]$} \\
\hline \multirow{3}{*}{ Master B } & 40 & 42.37 & 2.00 & 18.00 & 23.23 & 4.64 & 50.60 \\
\hline & 50 & 44.67 & 2.33 & 16.50 & 19.83 & 4.22 & 48.37 \\
\hline & 60 & 46.87 & 2.00 & 15.85 & 17.73 & 3.61 & 43.33 \\
\hline \multirow{3}{*}{ Entsar 1} & 40 & 36.95 & 2.33 & 21.90 & 35.13 & 7.20 & 54.43 \\
\hline & 50 & 40.00 & 2.33 & 18.98 & 30.87 & 6.79 & 51.20 \\
\hline & 60 & 43.10 & 2.33 & 17.22 & 28.37 & 5.97 & 48.27 \\
\hline \multicolumn{2}{|l|}{$\operatorname{LSD}(0.05)$} & 2.01 & N.S & 1.14 & 3.04 & 0.59 & 2.25 \\
\hline \multicolumn{2}{|c|}{ Cultivars $[C]$} & \multicolumn{6}{|c|}{ 2015-2016 season } \\
\hline \multicolumn{2}{|c|}{ Master B } & 46.38 & 2.22 & 14.56 & 21.41 & 4.54 & 49.58 \\
\hline \multicolumn{2}{|c|}{ Entsar 1} & 41.36 & 2.55 & 20.54 & 34.61 & 7.33 & 53.54 \\
\hline \multicolumn{2}{|c|}{$\operatorname{LSD}(0.05)$} & 2.39 & N.S & 2.12 & 0.46 & 0.21 & 1.09 \\
\hline \multicolumn{8}{|c|}{ Plant density $\left(m^{-2}\right)[D]$} \\
\hline \multicolumn{2}{|c|}{40} & 41.01 & 2.17 & 20.98 & 31.87 & 6.79 & 53.57 \\
\hline \multicolumn{2}{|c|}{50} & 43.45 & 2.33 & 18.66 & 27.22 & 5.70 & 51.38 \\
\hline \multicolumn{2}{|c|}{60} & 47.15 & 2.16 & 17.51 & 24.95 & 5.31 & 49.73 \\
\hline \multicolumn{2}{|l|}{ LSD (0.05) } & 1.54 & N.S & 1.01 & 2.27 & 0.26 & 1.08 \\
\hline \multicolumn{8}{|c|}{ Interaction [Cx $\mathrm{x}]$} \\
\hline \multirow{3}{*}{ Master B } & 40 & 43.50 & 2.33 & 18.77 & 25.07 & 5.65 & 51.50 \\
\hline & 50 & 46.00 & 2.00 & 17.37 & 20.33 & 4.13 & 49.80 \\
\hline & 60 & 49.63 & 2.33 & 16.55 & 18.83 & 3.84 & 47.43 \\
\hline \multirow{3}{*}{ Entsar 1} & 40 & 38.52 & 2.68 & 23.20 & 38.67 & 7.93 & 55.63 \\
\hline & 50 & 40.90 & 2.66 & 19.96 & 34.10 & 7.28 & 52.97 \\
\hline & 60 & 44.67 & 2.00 & 18.47 & 31.07 & 6.78 & 52.03 \\
\hline \multicolumn{2}{|l|}{ LSD (0.05) } & 2.18 & N.S & 1.42 & 3.21 & 0.37 & 1.53 \\
\hline
\end{tabular}

N.S: Not significant 
The enhancing effect of low plant population on plant growth parameters may be attributed to the lowest competition among plants on environmental sources (water, light and nutrients uptake) In this concern, the increasing in plant length by denser population ( 60 plant $\left.\mathrm{m}^{-2}\right)$, may be due to the competition among plants on light resulting in taller plant. Abu Seif et al.(2016)suggested that the increase in plant length by higher plant density reduce the enough light to reach the plants causing to accumulate of auxin which stimulating cell division and enlargement, as well as reducing gibberellins oxidation and this resulting to plant elongation. Meanwhile, branching did not affect by the different plant densities used probably refare to branching in pea is thought to be a form of apical dominance and as such is under the influence of different genetic and environmental factors(Welu,2015). Similar results were obtained by Nosser and Bhnan (2010); Yucel (2013); Bitew et al. (2014); Byan et al. (2015) and Sibhatu et al. (2016) who indicated that row spacing had significant effect on the vegetative growth of pea plants.

\section{c) Effect of the interaction between the two factors.}

Data in Table 2 reveal that the interaction between the two cultivars Master B and Entsar 1 had a significant effect for all studied morphological measurements in both studying seasons, except number of branches plant ${ }^{-1}$. In this respect, there is directly proportional relationship between each cultivar and plant density of plant length, where increased density due to increase in length. The tallest plant was recorded by the cv. Master B with plant density 60 plant $\mathrm{m}^{-2}$, Moreover, the other plant growth parameters, i.e. No. of leaves, fresh and dry weight plant $^{-1}$ had the same relationship but increased plant density due to the lowest values in this concern. On the other hand, the highest results of this parameters were obtained from the cultivar Entsar 1 with the density 40 plant $\mathrm{m}^{-2}$. Obtained results are in harmony with those reported by Nosser and Bhnan (2010); Yucel (2013) and Byan et al. (2015) on pea plants.

\section{Total Chlorophyll}

\section{a) Effect of cultivars:}

Data illustrated in Table 2 indicate that Entsar $1 \mathrm{cv}$. exhibited significantly the highest value of total chlorophyll of pea leaves compared with Master B cultivar during both growing seasons. Similar results were obtained by Byan (2015) on pea plant and Khairy (2013) on dry bean. Both stated that the total chlorophyll content in leguminous leaves were different according to the type and cultivar. 


\section{b) Effect of plant density:}

The lowest plant density ( 40 plant $\mathrm{m}^{-2}$ ) gave the heaviest total chlorophyll in pea leaves, followed in decreasing order by 50 and 60 plant $\mathrm{m}^{-2}$ in both growing seasons as shown in Table 2 . These results may be due to that the lowest plant density permit the sunlight receive to the plant which act the prencipale role in plant leaves to form chlorophyll molecules caused the increased of total chlorophyll pigments (Nosser and Bhnan, 2010 and Abu Seif et al.,2016). These results were confirm with those reported by El-Atabany( 2000) and Byan( 2015)on pea, Khairy( 2013) and El-Atabany(2015) on dry bean, who indicated that total chlorophyll was increased with the lowest plant density.

\section{c) Effect of the interaction between the two factors:}

The highest values of total chlorophyll of pea plant leaves were obtained by the interaction between Entsar $1 \mathrm{cv}$. with the two densities 40 plant $\mathrm{m}^{-2}$ in the first and 50 plant $\mathrm{m}^{-2}$ in the second rank compared with the other interaction treatments as shown in Table 2. Moreover, the cultivar Master B achieved higher result of the total chlorophyll content in its leaves with the lowest density 40 plant $\mathrm{m}^{-2}$.

\section{Total Green Pod Yield and Its Quality}

a) Effect of cultivars:

There were different significant effect between the two cultivars Master B and Entsar 1 for the characters of green pod quality, i.e. length, diameter and fresh weight pod ${ }^{-1}$ as well as number and fresh weight of green seed $\operatorname{pod}^{-1}$ as shown in Table 3. Moreover, all the parameters presented in Table 4, i.e. total green pod yield $\operatorname{plot}^{-1}(\mathrm{~kg})$ and fed. ${ }^{-1}$ (ton) as well as the fresh and dry weight of 1000 seeds $(\mathrm{g})$ showed different significant between the two cvs. The highest increased of total yield and pod quality can be obtained by the cultivar Entsar 1 during the two growing seasons. Entsar $1 \mathrm{cv}$. gave 36.95 and 36.43\% yield advantage over Master $\mathrm{B} \mathrm{cv}$. during the first and second seasons, respectively. These variations between the two cultivars in these features could be due to difference genetic factors of the variety and environment coditions ( Bitew et al.,2014 and Karkanis et al., 2016). These results agree with those reported by Nosser and Bhnan (2010); Yucel (2013) and Byan et al. (2015).

\section{b) Effect of plant density:}

Data in Tables 3 and 4 revealed that there were gradual decrease from

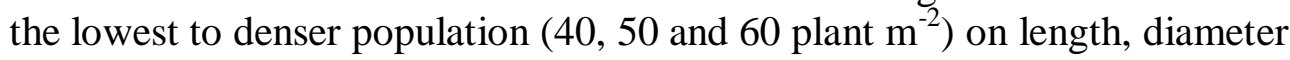


Table 3: Influence of cultivars and plant density $\left(\mathrm{m}^{-2}\right)$ on green pod quality of pea plants during 2014/2015 and 2015/2016 seasons.

\begin{tabular}{|c|c|c|c|c|c|c|}
\hline \multicolumn{2}{|c|}{ Characters } & $\begin{array}{l}\text { Pod length } \\
\quad(\mathrm{cm})\end{array}$ & $\begin{array}{c}\text { Pod } \\
\text { diameter } \\
(\mathbf{c m})\end{array}$ & $\begin{array}{l}\text { No of } \\
\text { seeds } \\
\text { pod }^{-1}\end{array}$ & $\begin{array}{c}\text { Fresh } \\
\text { weight } \\
\text { pod }^{-1} \\
\text { (g) }\end{array}$ & $\begin{array}{c}\text { Fresh weight } \\
\text { of green } \\
\text { seeds pod } \\
\text { (g) }\end{array}$ \\
\hline \multicolumn{2}{|l|}{ Cultivars [C] } & \multicolumn{5}{|c|}{ 2014-2015 season } \\
\hline \multicolumn{2}{|l|}{ Master B } & 9.96 & 1.15 & 7.82 & 6.19 & 3.24 \\
\hline \multicolumn{2}{|l|}{ Entsar 1} & 11.44 & 1.35 & 8.74 & 11.40 & 5.18 \\
\hline \multicolumn{2}{|c|}{ LSD (0.05) } & 0.78 & $\mathbf{0 . 0 7}$ & 0.69 & 0.19 & 0.14 \\
\hline \multicolumn{7}{|c|}{ Plant density $\left(m^{-2}\right)[D]$} \\
\hline \multicolumn{2}{|c|}{40} & 11.20 & 1.28 & 8.56 & 9.14 & 4.39 \\
\hline \multicolumn{2}{|l|}{50} & 10.55 & 1.25 & 8.17 & 8.80 & 4.31 \\
\hline \multicolumn{2}{|l|}{60} & 10.36 & 1.22 & 8.11 & 8.49 & 3.93 \\
\hline \multicolumn{2}{|c|}{ LSD (0.05) } & 0.25 & 0.05 & N.S & 0.19 & 0.18 \\
\hline \multicolumn{7}{|c|}{ 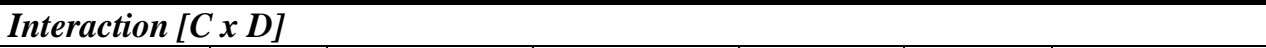 } \\
\hline \multirow{3}{*}{ Master B } & 40 & 10.17 & 1.17 & 8.07 & 6.48 & 3.41 \\
\hline & 50 & 10.00 & 1.15 & 7.67 & 6.32 & 3.42 \\
\hline & 60 & 9.73 & 1.13 & 7.72 & 5.77 & 2.91 \\
\hline \multirow{3}{*}{ Entsar 1} & 40 & 12.23 & 1.38 & 9.05 & 11.80 & 5.39 \\
\hline & 50 & 11.10 & 1.35 & 8.67 & 11.28 & 5.20 \\
\hline & 60 & 11.00 & 1.31 & 8.50 & 11.13 & 4.95 \\
\hline \multicolumn{2}{|l|}{ LSD (0.05) } & 0.35 & 0.07 & N.S & 0.28 & 0.25 \\
\hline \multicolumn{2}{|c|}{ Cultivars $[C]$} & \multicolumn{5}{|c|}{ 2015-2016 season } \\
\hline \multicolumn{2}{|c|}{ Master B } & 10.30 & 1.16 & 8.15 & 6.77 & 3.49 \\
\hline \multicolumn{2}{|c|}{ Entsar 1} & 11.68 & 1.40 & 9.05 & 11.79 & 5.49 \\
\hline \multicolumn{2}{|c|}{ LSD (0.05) } & 0.45 & 0.05 & $\mathbf{0 . 5 2}$ & $\mathbf{0 . 1 7}$ & 0.14 \\
\hline \multicolumn{7}{|c|}{ Plant density $\left(\mathrm{m}^{-2}\right)[\mathrm{D}]$} \\
\hline \multicolumn{2}{|c|}{40} & 11.45 & 1.31 & 8.73 & 5.59 & 4.69 \\
\hline \multicolumn{2}{|l|}{50} & 10.88 & 1.29 & 8.62 & 9.29 & 4.52 \\
\hline \multicolumn{2}{|l|}{60} & 10.65 & 1.25 & 8.45 & 8.96 & 4.25 \\
\hline \multicolumn{2}{|c|}{ LSD (0.05) } & 0.12 & 0.02 & N.S & 0.16 & 0.08 \\
\hline \multicolumn{7}{|c|}{ Interaction $\left[\begin{array}{lll}C & x & D\end{array}\right]$} \\
\hline \multirow{3}{*}{ Master B } & 40 & 10.50 & 1.19 & 8.33 & 6.96 & 3.64 \\
\hline & 50 & 10.25 & 1.17 & 8.19 & 6.85 & 3.58 \\
\hline & 60 & 10.15 & 1.13 & 7.93 & 6.51 & 3.24 \\
\hline \multirow{3}{*}{ Entsar 1} & 40 & 12.40 & 1.43 & 9.13 & 12.23 & 5.73 \\
\hline & 50 & 11.50 & 1.40 & 9.05 & 11.72 & 5.47 \\
\hline & 60 & 11.15 & 1.36 & 8.97 & 11.41 & 5.26 \\
\hline LSD (0.05) & & 0.40 & 0.03 & N.S & 0.23 & 0.11 \\
\hline
\end{tabular}

N.S: Not significant 
Table 4: Influence of cultivars and plant density $\left(\mathrm{m}^{-2}\right)$ on total green pod yield plot $^{-1}$ and feddan ${ }^{-1}$, as well as 1000 green and dry seed weight of pea during 2014/2015 and 2015/2016 seasons.

\begin{tabular}{|c|c|c|c|c|c|}
\hline \multicolumn{2}{|c|}{ Treatments } & $\begin{array}{c}\text { Total green } \\
\text { pod yield Plot } \\
(\mathbf{k g})\end{array}$ & $\begin{array}{l}\text { Total green pod } \\
\text { yield (ton) } \\
\text { fed. }^{-1}\end{array}$ & $\begin{array}{l}1000 \text { green } \\
\text { seeds weight } \\
\text { (g) }\end{array}$ & $\begin{array}{c}1000 \text { dry } \\
\text { seeds } \\
\text { weight }(\mathrm{g})\end{array}$ \\
\hline \multicolumn{2}{|c|}{ Cultivars $[C]$} & \multicolumn{4}{|c|}{ 2014-2015 season } \\
\hline \multicolumn{2}{|c|}{ Master B } & 5.662 & 3.293 & 437.03 & 108.48 \\
\hline \multicolumn{2}{|l|}{ Entsar 1} & 7.752 & 4.510 & 594.95 & 132.29 \\
\hline \multicolumn{2}{|c|}{$\operatorname{LSD}(0.05)$} & 0.024 & 0.046 & 32.61 & 21.96 \\
\hline \multicolumn{6}{|c|}{ Plant density $\left(m^{-2}\right)[D]$} \\
\hline \multicolumn{2}{|c|}{40} & 5.481 & 3.730 & 562.99 & 132.14 \\
\hline \multicolumn{2}{|l|}{50} & 6.714 & 3.915 & 502.83 & 122.77 \\
\hline \multicolumn{2}{|l|}{60} & 7.927 & 4.060 & 482.15 & 106.25 \\
\hline \multicolumn{2}{|c|}{$\operatorname{LSD}(0.05)$} & 0.013 & 0.036 & 33.21 & 3.32 \\
\hline \multicolumn{6}{|c|}{ 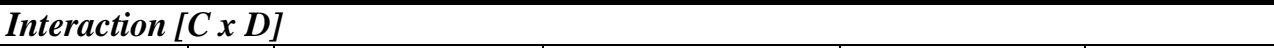 } \\
\hline \multirow{3}{*}{ Master B } & 40 & 4.617 & 3.160 & 463.94 & 117.00 \\
\hline & 50 & 5.688 & 3.300 & 433.87 & 110.47 \\
\hline & 60 & 6.682 & 3.420 & 413.33 & 97.96 \\
\hline \multirow{3}{*}{ Entsar 1} & 40 & 6.345 & 4.700 & 662.04 & 147.28 \\
\hline & 50 & 7.740 & 4.530 & 571.85 & 135.06 \\
\hline & 60 & 9.173 & 4.700 & 550.97 & 114.53 \\
\hline \multicolumn{2}{|l|}{ LSD (0.05) } & 0.019 & 0.051 & 46.97 & 4.69 \\
\hline \multicolumn{2}{|c|}{ Cultivars $[C]$} & \multicolumn{4}{|c|}{ 2015-2016 season } \\
\hline \multirow{2}{*}{\multicolumn{2}{|c|}{$\begin{array}{c}\text { Master B } \\
\text { Entsar 1 }\end{array}$}} & 5.879 & 3.423 & 436.22 & 114.17 \\
\hline & & 8.027 & 4.670 & 634.93 & 139.71 \\
\hline \multicolumn{2}{|c|}{$\overline{\operatorname{LSD}(0.05)}$} & 0.014 & 0.033 & 39.87 & 1.83 \\
\hline \multicolumn{6}{|c|}{ Plant density $\left(m^{-2}\right)[D]$} \\
\hline \multicolumn{2}{|l|}{40} & 5.703 & 3.875 & 589.52 & 140.08 \\
\hline \multicolumn{2}{|l|}{50} & 6.975 & 4.040 & 530.63 & 138.61 \\
\hline \multicolumn{2}{|c|}{60} & 8.180 & 4.225 & 486.56 & 112.14 \\
\hline \multirow{2}{*}{\multicolumn{6}{|c|}{$\begin{array}{c}\operatorname{LSD}(0.05) \\
\text { Interaction }[C \times x]\end{array}$}} \\
\hline & & & & & \\
\hline \multirow{3}{*}{ Master B } & 40 & 4.860 & 3.240 & 476.85 & 126.76 \\
\hline & 50 & 5.832 & 3.430 & 453.46 & 114.62 \\
\hline & 60 & 6.945 & 3.600 & 378.333 & 101.13 \\
\hline \multirow{3}{*}{ Entsar 1} & 40 & 6.547 & 4.510 & 702.19 & 153.39 \\
\hline & 50 & 8.118 & 4.650 & 607.80 & 142.59 \\
\hline & 60 & 9.416 & 4.850 & 594.79 & 123.15 \\
\hline \multicolumn{2}{|l|}{ LSD (0.05) } & 0.170 & 0.053 & 18.89 & 5.37 \\
\hline
\end{tabular}

N.S: Not significant 
and fresh weight pod $^{-1}$, average fresh and seed pod $^{-1}, 1000$ seeds fresh and dry weight. The highest values of these parameters were observed from the density 40 plant $\mathrm{m}^{-2}$. On the other hand, data in Table 4 show clearly that the increase of total green pod yield either per plot or feddan can produced by increasing plant density 60 plant $\mathrm{m}^{-2}$. Such increment of pod characters and total yield by the low density may be due to sowing pea at low plant population 40 plant $\mathrm{m}^{-2}$ increased plant growth, concentrated the chlorophyll pigments in leaves(as shown in Table 2) which consecuantly affect on pods yield and its quality. Moreover,the increase in total yield either per plot or feddan seems to be resulted from increasing number of plants per unit area,i.e. 60 plant $\mathrm{m}^{-2}$ which may be more critical than number of pods plant ${ }^{1}$ (Abu Seif et al. , 2016 and Sibhatu et al.,2016). On the other hand,the number of seeds per pod had no significant effect with all plant densities used during the two studying seasons.

As for pod characters, Nosser and Bhnan(2010) reported that cultivating on one side followed by the two sides of the ridge recorded increase of pod weight, number of seeds per pod and weight of 100 seeds while three sides of ridges to increase the total green yield. Similar findings were reported by Sajid et al. (2012); Salem et al. (2012); Mojaddam and Nouri (2014); Yucel (2013); Bitew et al. (2014); Byan et al.(2015) and Sibhatu et al. (2016) on different legumes.

\section{c) Effect of the interaction between the two factors:}

Data in Tables 3 and 4 indicate that Entsar $1 \mathrm{cv}$. combined with 40 plant $\mathrm{m}^{-2}$ gave the highest values of pod characters, i.e. length, diameter, fresh weight of pod and its seeds, as well as the fresh and dry weight of 1000 seeds. In this respect, the maximum total green pod yield per plot and feddan were achieved by the cultivar Entsar 1 with the highest density 60 plant $\mathrm{m}^{-2}$, the increase in total yield fed. ${ }^{-1}$, reach to 48.73 and $49.69 \%$ compare with Master B cv., respectively in the both growing seasons, Mean while, the number of seeds per pod did not appear any significant effect in this interaction. These results are in conformity with those stated by Nosser and Bhnan, (2010); Bitew et al., (2014) and Byan et al., (2015).

Conclusively, it can be recommended to cultivate the new pea cultivar Entsar 1 under clay soil conditions at the low planting density 40 plant $\mathrm{m}^{-2}$ to obtain the highest values of plant growth characters, total chlorophyll, maximum total green yield with best green pod and seed quality. 


\section{REFERENCES}

Abu Seif,Y.I.,S.E.D.M.EL-Miniawy,N.A.I.Abu El-Azm, A. Z. Hegazi (2016). Response of snap bean growth and seed yield to seed size, plant density and foliar application with algae extract. Ann. Agric. Sci.,61(2):187-199.

Bitew, Y., F. Asargewe and O. Beshir (2014). Effect of plant spacing on the yield and yield component of field pea (Pisum sativum L.) at Adat, North Western Ethiopia. Agric. Forestry and Fisheries, 3 (5): 368-373.

Byan, U.A.I., N.M.M. El-Shimi and A.A. Hamed (2015). Effect of sowing date and plant density on the productivity of some new garden peas cultivars, Egypt. J. Appl. Sci., 30 (4): 228-250.

Carranca, C., A De. Varennes and D. Rolston (1999). Biological nitrogen fixation by faba bean, pea and chickpea, under field conditions, estimated by the $15 \mathrm{~N}$ isotope dilution technique. Europ. J. Agro., 10 (1): 49-56.

Dahl, W. J., L.M. Foster and R.T. Tyler (2012). Review of the health benefits of peas (Pisum sativum L.). British J. Nutri., 108:3-10.

El-Atabany, A. M. M.S. (2000). Physiological studies on pea plants. M. Sc. Thesis, Fac. Agric., Zagazig Univ., 124 p.

El-Atabany, A.M.(2015). Effect of sowing and foliar spary by safety natural materials on yield and quality of snap bean (Phaseolus vulgars L.). Ph. D. Thesis , Fac. Agric., Benha Univ.

Karkanis, A., N. Georgia, K. Chairs-Konstantina, P. Aurelio, B. Dimitrios and S. Dimitrios (2016). Field pea in European cropping systems: Adaptability, biological nitrogen fixation and cultivation practices. Not. Bot. Horti. Agrob., 44 (2): 325-336.

Khairy, E.A. F. (2013). Effect of plant population and sowing dates on growth and yield of dry bean (Phaseolous vulgaris L.). Ph. D. Thesis, Fac. Agric., Suez Canal, Univ., 93 p.

Mojaddam, M. and A. Nouri (2014). The effect of sowing date and plant density on yield and yield components of cowpea. Bull. Environ. Pharma. Life Sci., 3(8): 31-36.

Munakamwe, Z., G.D. Hill and B.A. McKenzie (2012). Yield response to pea (Pisum sativum L.) genotype, population and sowing date. The Open Agric. J., 6: 47-56. 
Nosser, M. A. and E. Y. Bhnan (2010). The productivity of pea was improved by using biofertilization and the best intensification methods. Ann. Agric. Sci., Ain Shams Univ., 55 (2): 285-293.

Piotrowska, A. and E. Wilczewski (2012). Effects of catch crops cultivated for green manure and mineral nitrogen fertilization on soil enzyme activities and chemical. Geoderma, 189-190:72-80.

Sajid, M., A.Rab, N.A. Fazaliwahid, I. Jan, I. Ahmed, I.A. Khan and M.A. Khan (2012). Effect of herbicides and row spacing on the growth and yield of pea. Pak. J. Weed Sci. Res., 18 (1): 1-13.

Salem, A. K.H., Z.M. Abd El-Naby and N.M.N. Nasr (2012). Influence of seeding rate and row spacing on forage yield and quality of cowpea (Vigna sinenses L.) grown in three locations. J. Plant Prod., Mansoura Univ., 3(2): 217-227.

SAS institute (2008). SAS User Guides Version 9.2. SAS Institute Inc. Cary, North Carolina, USA.

Sibhatu, B., H. Berhe, G. Gebrekorkos and K. Abera (2016). Determination of planting spacing for improved yield and yield components of Dekoko (Pisum sativum L.) var. abyssinicum at raya valley, Northern Ethiopia. Afr. J. Plant Sci., 10 (8): 157-161.

Swiatecka, D., A. Swiatecki, H. Kostyra, F.K. M. Darmochwa and E. Kostyra (2010). The impact of pea protein hydrolysates on bacterial physiological activity - An in vitro study. Inter. J. Food Microbio., 140 (2-3): 263-270.

Urbatzka, P., R. Grab, T. Haase, C. Schuler and J. Heb (2012). Influence of different sowing dates of winter pea genotypes on winter hardiness and productivity as either winter catch crop or seed legume, Europ. J. Agron., 40:112-119.

Welu, G. (2015). Effects of plant density on the yield components of Haricot bean (Phasoulous vulgaris L.). J. Natural Sci. Res., 5 (5): 37-41.

Yucel, D.O. (2013). Impact of plant density on yield and yield components of pea (Pisum sativum L.) cultivars. Arpn J. Agric. \& Biolog. Sci., 8 (2):L 169-174. 


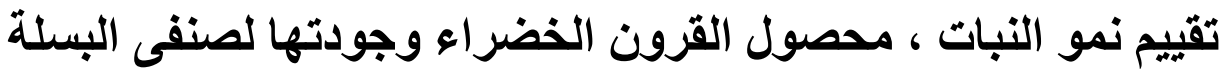

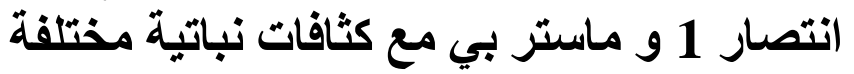

\author{
وفاء عادل فكري*-_ رواء صلاح الشطوري

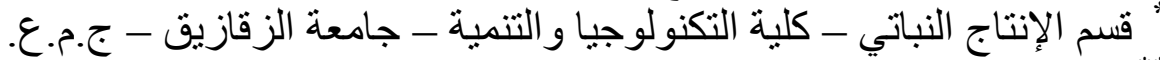

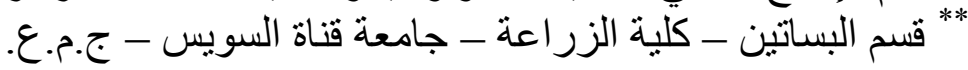

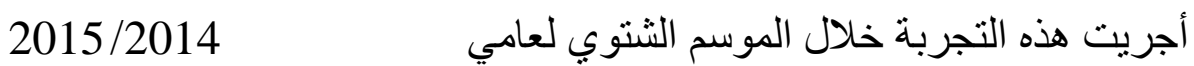

و 2016/2015 بمزرعة التجارب (غزالة ـ الزقازيق) بكلية التكنولوجيا و التنمية

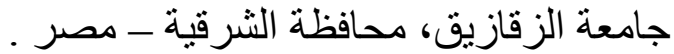

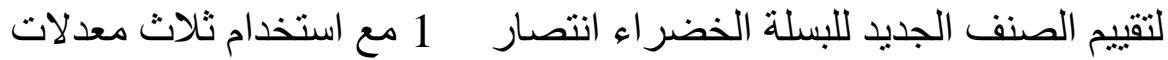

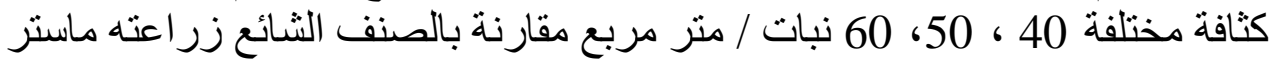

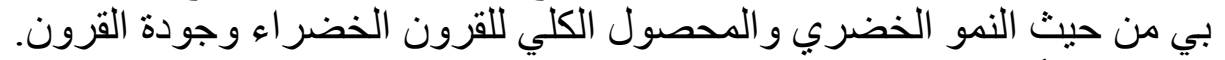

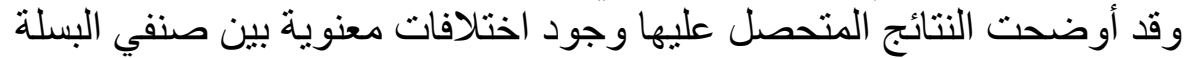

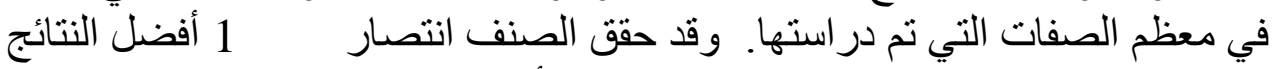
لمعظم صفات النمو الخضري متمثنا في عدد الأوراق و الوزن الغض و الجاف لكل

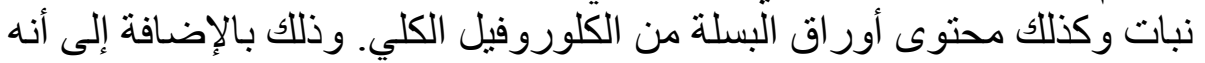

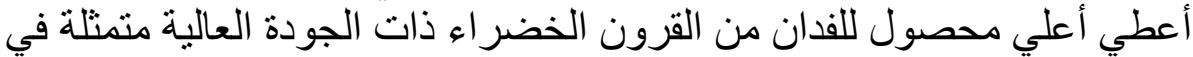

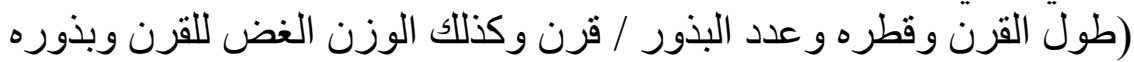
الخضر اء) والوزن الغض والجاف لعدد 1000 بذرة. بينما سجل الصنف ماستون ماستر بى اعلى قيمة لصفة طول النبات فقط الصناء

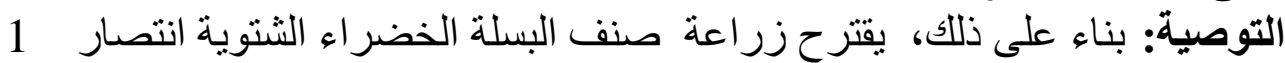

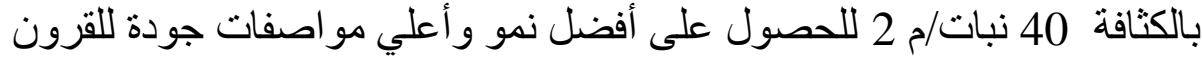

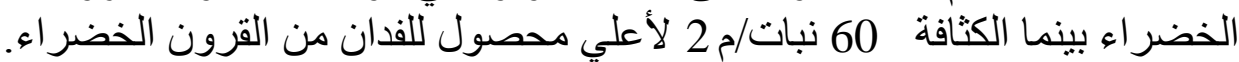

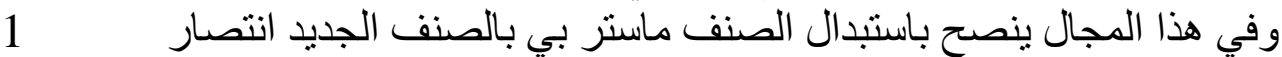

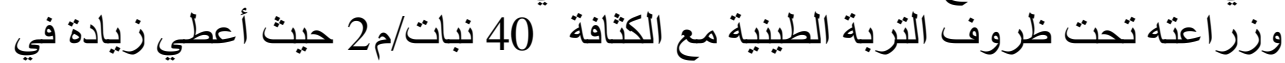

المحصول بنسبة 48.73، 49.69\% على التو الي خلال موسمي النمو فى هذه 